Mook, Hann, and Quarter (2012)

ANSERJ

Vol. 3, No 1

Spring / Printemps, 2012

pp. $42-58$

Canadian Journal of Nonprofit and Social Economy Research

Revue canadienne de recherche sur les OBSL et l'économie sociale

\title{
Understanding the Rural Tilt among \\ Financial Cooperatives in Canada
}

\author{
Laurie Mook \\ Arizona State University \\ Jennifer Hann and Jack Quarter \\ University of Toronto
}

\begin{abstract}
This mixed methods study examines whether the rural/urban distribution of credit union/caisse populaire branches differs significantly from the general urban/rural demographic pattern in Canada. It also explores whether their distribution is different from that of banks, looking at the cases of Québec and Atlantic Canada. The study finds a rural tilt among financial cooperatives in Canada, and seven key informants present their views on the results. Their responses are categorized in two main themes: why financial cooperatives are overrepresented in rural and small town areas, and why they are under-represented in urban ones. A discussion follows, and directions for further study are provided.

\section{RÉSUMÉ}

Cette étude utilisant des méthodes combinées examine si la distribution des succursales de coopératives d'épargne et de crédit / caisses populaires en milieu rural et urbain diffère de façon importante de la tendance démographique générale des milieux urbains et ruraux au Canada. Elle aborde aussi la question de savoir si leur distribution est différente de celle des banques en observant le cas du Québec et du Canada atlantique. L'étude révèle une tendance rurale chez les coopératives financières du Canada, et sept répondants clés donnent leur opinion sur les résultats. Les réponses des intervenants sont divisées en deux thèmes principaux : pourquoi les coopératives sont surreprésentées dans les milieux ruraux et les petites villes et pourquoi elles sont sous-représentées dans les milieux urbains. Un débat s'ensuit, et des lignes directrices sont fournies aux fins d'une étude plus approfondie.
\end{abstract}

Keywords / Mots clés : Credit unions; Caisses populaires; Financial cooperatives; Rural; Urban / Coopératives d'épargne et de crédit; caisses populaires; coopératives financières; milieu rural; milieu urbain 


\section{Mook, Hann, and Quarter (2012)}

\section{INTRODUCTION}

Each year the Co-operatives Secretariat (a unit within Agriculture Canada) publishes a series of reports on the state of cooperatives within Canada. Some of these reports are regular publications, such as Co-operatives in Canada and Top 50 Non-financial Co-operatives in Canada, and others are one-off research reports, such as Profile of Canadian Agricultural Co-operatives (1998-2002). In reading these reports, one is struck by at least two very clear patterns: first, the economic dominance of agriculture, broadly speaking, within Canadian cooperatives. These "agricultural" cooperatives include farm marketing cooperatives that dominate the top 50 non-financial cooperatives and account for about one-quarter of revenues; farm supply cooperatives (fertilizers and chemicals, animal feed, seed, building materials, and petroleum products); cooperatives in fishing; and production co-ops in services such as grazing, agricultural machinery, animal reproduction, forestry, and handicrafts, the largest two components being management of feeder finance operations and grazing operations. The most recent figures indicate that agricultural cooperatives represent only $15 \%$ of non-financial cooperatives in Canada, but about $45 \%$ of revenues (Co-operatives Secretariat, 2011). The economic dominance of agricultural cooperatives occurs at a time when Canada is heavily urban in its makeup.

The second pattern or trend is the striking growth of cooperatives in public services-particularly in housing but also in childcare, healthcare, and home care. Together, these cooperatives account for about half of nonfinancial cooperatives in Canada, and housing cooperatives alone account for about $40 \%$. Unlike agricultural cooperatives, these cooperatives in public services are predominantly urban and rely upon government programs. Although they make up a growing portion of non-financial cooperatives in Canada, they represent a relatively small portion of revenues.

Our previous work discusses these patterns (Quarter, Mook, \& Hann, 2012) and piqued our curiosity about financial cooperatives in Canada-that is, credit unions and caisses populaires. Do they also follow the pattern of rural dominance? This article presents the data from our analysis of credit unions and caisses populaires in Canada.

Canada has had a long and strong tradition for developing credit unions since their inception in 1901 in Lévis, Québec (MacPherson, 1979, 1995, 1999, 2012). This study examines the extent to which credit unions and caisses populaires moved with the demographic change in Canada away from their rural, agricultural tradition to reflect population distribution. In that regard, we ask three questions:

1. Does the rural/urban distribution of credit union/caisse populaire branches differ significantly from the general urban/rural demographic pattern in Canada?

2. Do credit union/caisse populaire branches differ from bank branches in their urban/rural distribution?

3. How can these data be explained?

\section{BACKGROUND}

The recent research literature on credit unions has addressed their challenges primarily in the context of the transformation into larger units and the impact that change has had on membership participation. In a historical analysis of the credit union development in Canada, MacPherson (2012) argues: 


\section{Mook, Hann, and Quarter (2012)}

The Canadian credit union movement has gone through a series of periods or stages, particularly over the last eighty years, which can be understood as: formative, stabilizing, building, re-examining, and reformulating. The last two stages, re-examining and reformulating, are cyclical because credit unions are constantly buffeted by internal and external pressures and the need to adapt. The great challenge they face is how, amid those changes, they can retain their commitment to members, co-operative structures, community relations, developing appropriate government relations, and co-operative management. (p. 37)

Senior management who feel that mergers into larger units are in the best economic interests of the credit union have to convince their membership of the validity of this viewpoint. Board members, on the other hand, who are a different stakeholder group than management, are obliged to listen to the people from their community who elected them; this can produce a dilemma that Cornforth refers to as "the tension between the conformance and performance" (2002, p. 4; see also 2004). The concern in organizations such as credit unions-or memberbased organizations in general-is that management will become too powerful and the board will be a weak representative of the membership (Spear, 2004). In a study of credit unions in Saskatchewan, Mavenga (2010) expresses the concern that mergers may cause credit unions to become more like banks and that they may become disconnected from their local communities. In response to such concerns, Ketilson and Brown (2011) set out a series of proposals to increase member voice and participation within larger organizations.

Another factor comes into play in democratic member-based organizations: decision-making can be timeconsuming, especially when the issues are of great importance to the stakeholders. Addressing this issue in a different context, that of Aboriginal/government negotiations, Benson (2002) states: "[O]nly the long slow process of trust and relationship-building can provide the basis for successful multiparty institutional negotiations" (p. vii). Although the context differs, Benson's point could be generalized to credit union change: multiple stakeholders are involved, and satisfying the needs of each group can be a time-consuming process.

Although decision-making in banks and trying to create consensus around major issues also can be time consuming, the interests of senior management and of board members representing shareholders of a bank are likely to be aligned around increasing profits and expanding markets. In democratically structured organizations such as credit unions, however, there may be less agreement between management and board members representing the broader membership. Therefore, banks may be better positioned to initiate policy changes than credit unions, including the closure of branches.

\section{RATIONALE}

Little research bears directly on the issue that this article addresses: the demographic patterns of credit unions and caisses populaires. As noted, an earlier study by the authors on Canadian cooperatives found that there were two broad demographic groupings: cooperatives in such public services as housing, childcare, healthcare and home care that rely heavily on government funding programs and are found primarily in urban centres; and cooperatives that are financially self-sufficient and that market services either to a membership or to the broader public, found primarily in rural settings and small communities (Quarter et al., 2012; Quarter, Mook, \& Armstrong, 2009).

This study is exploratory and proceeds inductively. We first seek to determine the proportion of financial cooperatives in Canada located in rural areas and small towns; next, we attempt to determine whether the urban/rural distribution of credit union/caisse populaire outlets differs from that of bank branches (looking at the cases of Québec and Atlantic Canada); and finally, we explore possible explanations for the distribution of credit 
union/caisse populaire outlets. The explanations, as noted, are speculative, but nevertheless have value and raise issues that could be explored deductively.

\section{METHODOLOGY AND RESULTS}

This study utilizes a mixed methods approach, combining quantitative and qualitative approaches to research (Creswell, 1998, 2003; Creswell \& Plano Clark, 2007; Tashakkori \& Teddlie, 2003). The quantitative study is presented first, followed by the qualitative study.

\section{Quantitative study}

The purpose of the quantitative research was twofold: a) to determine whether credit union and caisse populaire outlets corresponded to the population distribution in Canada; and b) to determine whether the distribution of credit union and caisse populaire branches differed from that of bank branches. The first step was to compile a database of credit unions from those posted on credit union central websites; ${ }^{1}$ subsequently, we compiled a database of caisses populaires, based upon information obtained from Desjardins (Canada's largest cooperative financial group, with most of its operations in the province of Québec). Once these steps were completed, we mapped the credit union/caisse populaire locations by the population size of the community in which they were located, using a combination of information drawn from Statistics Canada (2008) and Google Maps.

Excepting Québec, we classified community size as follows: under 10,000 (rural and small towns); 10,000 to under 100,000; 100,000 to under 1 million; and 1 million and over. For the classification of "rural and small towns," we used the criteria put forth by Du Plessis, Beshiri, Bollman, \& Clemenson (2001, p. 11): "the population living in towns and municipalities outside the commuting zone of larger urban centres, i.e., outside the commuting zone of centres with population of 10,000 or more." For Québec, we relied on Desjardins' classifications for the distribution of their branches by community size. The categories were as follows: less than 3,$000 ; 3,000$ to less than 5,$000 ; 5,000$ to less than 8,$000 ; 8,000$ to less than 12,$500 ; 12,500$ to less than 30,000 ; 30,000 to less than 57,$000 ; 57,000$ to less than 200,$000 ; 200,000$ to less than 700,000 ; and over 700,000 . For Québec, rural and small-town communities were considered to be those with a population under 8,000 .

To compare credit union locations to banks, we chose two regions for our initial exploration: Atlantic Canada, because the data were manageable, and Québec because Desjardins made the data available to us. For Atlantic Canada, we mapped the bank branches by community size using the same procedure as for credit unions (see above). For Québec, Desjardins provided a table of banks by community size using the same categories as for caisses populaires.

\section{Quantitative data findings}

We begin by presenting the data on credit union branches in English Canada. Table 1 shows the population distribution in English Canada by province on the left and credit union distribution by community size on the right. For English Canada as a whole, about $41 \%$ of credit union branches (814) can be found in communities

with a population of under 10,000, or what we label rural and small towns (RST). In settings with a population over 10,000 , we find about $59 \%$ of credit union branches $(1,170)$. When credit union distribution is compared to the population distribution by community size for English Canada, it is evident that credit unions are more heavily clustered in RST areas, which represent only $18 \%$ of the population. 
Mook, Hann, and Quarter (2012)

\section{Table 1: Credit union branch locations in English Canada by community size}

\begin{tabular}{|c|c|c|c|c|c|c|c|c|c|c|}
\hline & $\begin{array}{c}\text { Total } \\
\text { population }\end{array}$ & Population & distribution & by communit & ty size (\%) & \begin{tabular}{|c|} 
Total \\
credit \\
union \\
branches \\
\end{tabular} & Credit & $\begin{array}{l}\text { union bra } \\
\text { commun }\end{array}$ & $\begin{array}{l}\text { ch distribut } \\
\text { y size (\%) }\end{array}$ & on by \\
\hline & & $\begin{array}{r}\text { Under } \\
10,000 \\
\text { (RST) } \\
\end{array}$ & $\begin{array}{r}10,000- \\
99,999 \\
\end{array}$ & $\begin{array}{r}100,000- \\
999,999 \\
\end{array}$ & 1 milliont & & $\begin{array}{r}\text { Under } \\
10,000 \\
\text { (RST) } \\
\end{array}$ & $\begin{array}{r}10,000- \\
99,999 \\
\end{array}$ & $\begin{array}{r}100,000- \\
999,999 \\
\end{array}$ & 1 million+ \\
\hline PEI & 135,851 & 44.96 & 55.04 & 0.00 & 0.00 & 14 & 78.57 & 21.43 & $\mathrm{~N} / \mathrm{A}$ & $\mathrm{N} / \mathrm{A}$ \\
\hline Nova Scotia & 913,462 & 35.84 & 11.75 & 52.41 & 0.00 & 90 & 57.78 & 5.56 & 36.67 & $\mathrm{~N} / \mathrm{A}$ \\
\hline New Brunswick & 729,997 & 41.52 & 24.40 & 34.08 & 0.00 & 118 & 61.86 & 18.64 & 19.49 & $\mathrm{~N} / \mathrm{A}$ \\
\hline Nfld. \& Labrador & 505,469 & 54.14 & 10.03 & 35.83 & 0.00 & 42 & 69.05 & 7.14 & 23.81 & $\mathrm{~N} / \mathrm{A}$ \\
\hline Ontario & $12,160,282$ & 11.91 & 8.38 & 37.67 & 42.05 & 545 & 16.51 & 12.66 & 45.14 & 25.69 \\
\hline Manitoba & $1,148,401$ & 32.34 & 7.17 & 60.49 & 0.00 & 215 & 58.60 & 6.05 & 35.35 & $\mathrm{~N} / \mathrm{A}$ \\
\hline Saskatchewan & 968,157 & 40.40 & 15.30 & 44.30 & 0.00 & 308 & 82.14 & 5.19 & 12.66 & $\mathrm{~N} / \mathrm{A}$ \\
\hline Alberta & $3,290,350$ & 21.21 & 14.53 & 0.00 & 64.26 & 231 & 38.96 & 13.85 & $\mathrm{~N} / \mathrm{A}$ & 47.19 \\
\hline British Columbia & $4,113,487$ & 13.06 & 19.65 & 15.84 & 51.45 & 421 & 21.38 & 19.95 & 14.96 & 43.71 \\
\hline Total (except Québec) & $23,965,456$ & $18.40 \%$ & $12.30 \%$ & $30.31 \%$ & $38.99 \%$ & 1,984 & $41.03 \%$ & $12.45 \%$ & $24.70 \%$ & $21.82 \%$ \\
\hline
\end{tabular}

In all provinces, there was a greater proportion of credit unions in rural and small-town locations when compared to population distribution. The extent of the pattern varied by province, but only in degree, with Saskatchewan credit unions being the most prevalent in rural communities (82\%) and Ontario's the least $(16.5 \%)$ (see Figure 1).

Figure 1: Percentage of credit union branches and population in rural and small towns (populations under 10,000*)

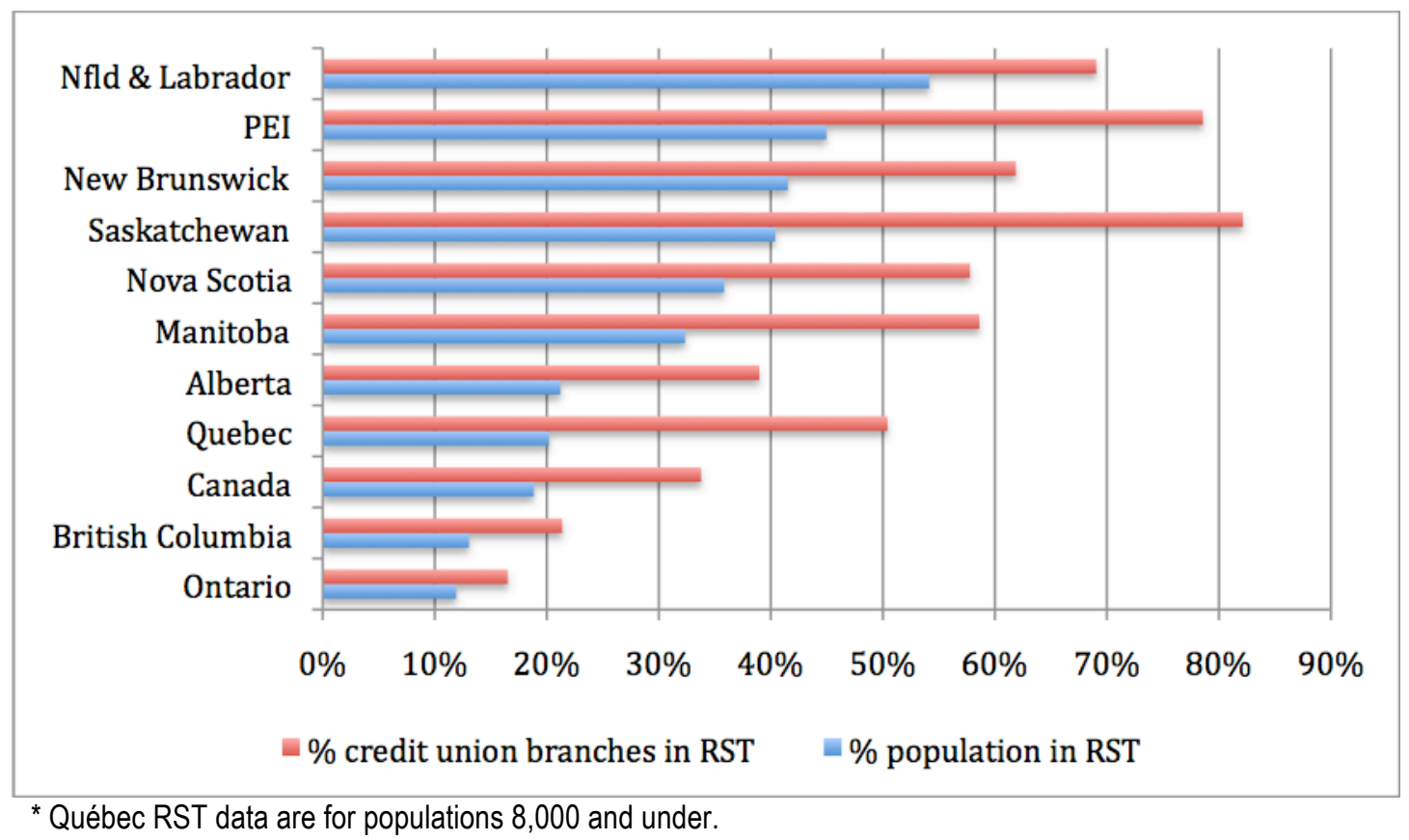


Table 2 examines caisses populaires in Québec, through data collected by the Desjardins system that includes both branches and service outlets. ${ }^{2}$ These data have the added strength of including not only caisse populaire locations but also banks, so that we can compare the representation of banks and caisses populaires in those locations.

Table 2: Desjardins branch locations in Québec by community size, 2010

\begin{tabular}{|c|c|c|c|c|c|c|c|c|c|c|}
\hline & & \multicolumn{4}{|c|}{$\begin{array}{l}\text { Population distribution } \\
\text { by community size (\%) }\end{array}$} & \multirow[t]{2}{*}{$\begin{array}{c}\text { Total } \\
\text { credit union } \\
\text { branches }\end{array}$} & \multicolumn{4}{|c|}{$\begin{array}{l}\text { Credit union branch } \\
\text { Distribution by community size (\%) }\end{array}$} \\
\hline & $\begin{array}{c}\text { Total } \\
\text { Population }\end{array}$ & $\begin{array}{c}\text { Under } \\
10,000 \text { (RST) }\end{array}$ & $\begin{array}{c}10,000- \\
99,999\end{array}$ & $\begin{array}{l}100,000= \\
999,999\end{array}$ & $\begin{array}{c}1 \\
\text { million+ }\end{array}$ & & $\begin{array}{l}8,000 \text { and } \\
\text { under (RST) }\end{array}$ & $\begin{array}{r}\text { Over } 8,000 \\
200,000\end{array}$ & $\begin{array}{l}\text { More than } \\
200,000\end{array}$ & $\begin{array}{c}1 \\
\text { million+ }\end{array}$ \\
\hline Québec & $7,546,131$ & $20.20 \%$ & $12.01 \%$ & $19.61 \%$ & $48.18 \%$ & 14 & $50.42 \%$ & $19.65 \%$ & $29.93 \%$ & - \\
\hline
\end{tabular}

Source: Statistics Canada (2008), 2006 Census

For Québec, the data show a similar pattern to credit unions in English Canada: $50 \%$ of Desjardins branches are in communities of 8,000 and under, whereas only $20 \%$ of Québeckers live in such communities; strikingly, almost $36 \%$ of caisses populaires are in communities of 3,000 or less. In cities with a population of 700,000 or more, we find about $30 \%$ of Desjardins branches, whereas nearly half of Québec's population is in comunities of 1 million or more.

Table 3: Desjardins and bank branches by community size in Québec

\begin{tabular}{|c|c|c|c|c|}
\hline $\begin{array}{c}\text { Size of the } \\
\text { municipality } \\
\text { (average } \\
\text { population) }\end{array}$ & $\begin{array}{c}\text { Presence } \\
\text { of } \\
\text { Desjardins }\end{array}$ & $\begin{array}{c}\text { Percent } \\
\text { (\%) }\end{array}$ & $\begin{array}{c}\text { Presence } \\
\text { of banks }\end{array}$ & $\begin{array}{c}\text { Percent } \\
(\%)\end{array}$ \\
\hline $\begin{array}{c}\text { More than } \\
\mathbf{7 0 0 , 0 0 0}\end{array}$ & 399 & 29.93 & 705 & 64.21 \\
\hline $\mathbf{2 0 0 , 0 0 0}$ & 88 & 6.60 & 87 & 7.92 \\
\hline $\mathbf{5 7 , 0 0 0}$ & 96 & 7.20 & 74 & 6.74 \\
\hline $\mathbf{3 0 , 0 0 0}$ & 44 & 3.30 & 41 & 3.73 \\
\hline $\mathbf{1 2 , 5 0 0}$ & 34 & 2.55 & 37 & 3.37 \\
\hline $\mathbf{8 , 0 0 0}$ & 47 & 3.53 & 51 & 4.64 \\
\hline $\mathbf{5 , 0 0 0}$ & 47 & 3.53 & 43 & 3.92 \\
\hline $\mathbf{3 , 0 0 0}$ & 102 & 7.65 & 42 & 3.83 \\
\hline $\begin{array}{c}\text { Less than } \\
\mathbf{3 , 0 0 0}\end{array}$ & 476 & 35.71 & 18 & 1.64 \\
\hline Total & $\mathbf{1 , 3 3 3}$ & & $\mathbf{1 , 0 9 8}$ & \\
\hline
\end{tabular}

Table 3 compares the prevalence in Québec of bank branches to Desjardins branches by community size. The Desjardins branches included 450 distinct caisses populaires at the end of 2010 (Desjardins, 2011). Although they are integrated within the Desjardins system, they operate with greater autonomy than a bank branch. Table 3 shows clearly the disproportionate number of caisses populaires in RST areas, when compared to bank branches as a group. Communities of less than 3,000 contain almost $36 \%$ of Desjardins locations, but less than $2 \%$ of bank branches. Communities of up to 8,000 residents contain over half of Desjardins branches and only $14 \%$ of bank branches. The major difference, as noted, is in the communities of less than 3,000 . When cities of 700,000 or more are considered, they contain $64 \%$ of bank branches and only $30 \%$ of Desjardins branches. 
Finally, to explore the bank branch/caisse populaire comparison in English Canada, we look at Atlantic Canada. We chose this part of Canada because it is smaller and therefore the data collection was more manageable. Credit unions and caisses populaires have also on average been in business in Atlantic Canada for over 60 years (Thériault, Skibbens, \& Brown, 2008). Data were collected in May and June 2011 from institution websites, provincial government websites, and Google Maps. ${ }^{3}$ Table 1 already illustrates that although there is some variation in degree, in all provinces credit unions are over-represented relative to the population in RST areas and under-represented in larger centres. Figure 2 indicates that for banks, their representation in RST areas more closely approximates the percentage of the population that is RST. Credit unions, as compared to the population distribution, are more heavily represented in RST areas.

Figure 2: Distribution of banks and credit unions in Atlantic Canada, 2010

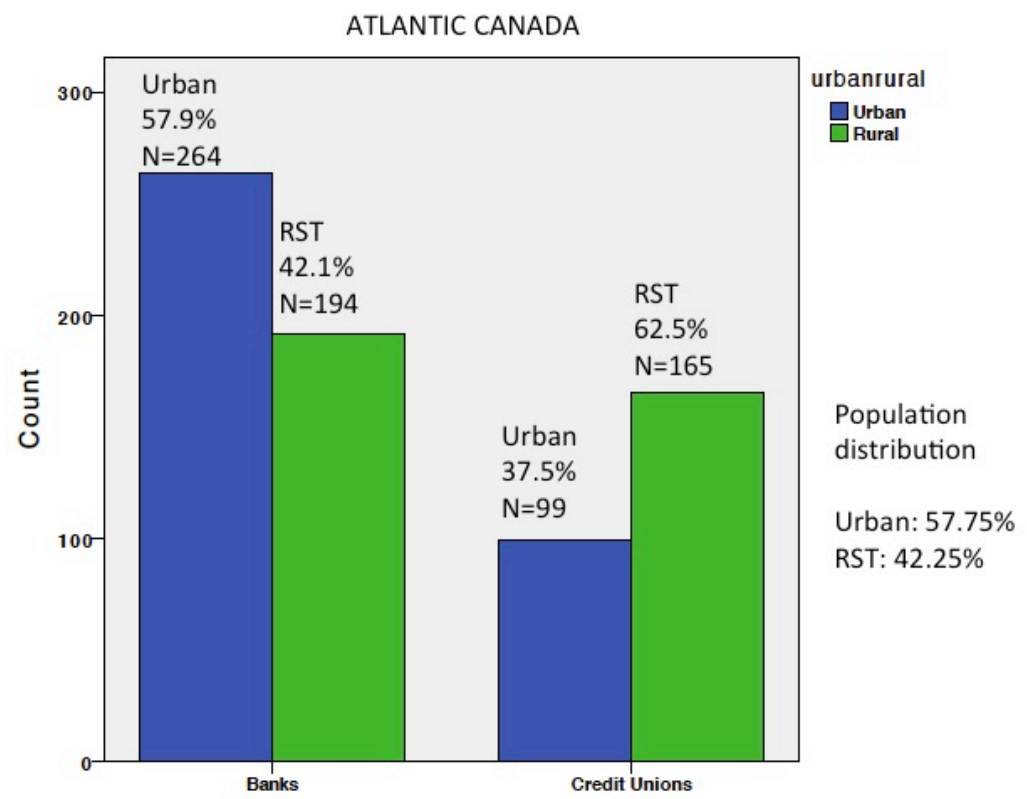

Source for population statistics: Statistics Canada (2008), 2006 Census.

Note: Missing: 0; Chi-square $=27.820$, d.f. $=1, p<.000 ;$ Cramer's V $=.197$

As shown in Figure 3, for Atlantic Canada, the overall percentage of credit union branches of the total of credit union and bank branches in RST areas (populations under 10,000) is 46; the percentage of banks is 54 . In urban areas (that is, everything that is not RST), the spread is more extreme: credit unions are $27 \%$ of the total while banks are $73 \%$. In urban areas credit unions are under-represented as a percentage of financial institutions, while in RST areas banks and credit unions are more evenly represented. 
Figure 3: Distribution of banks and credit unions in Atlantic Canada RST areas, 2010

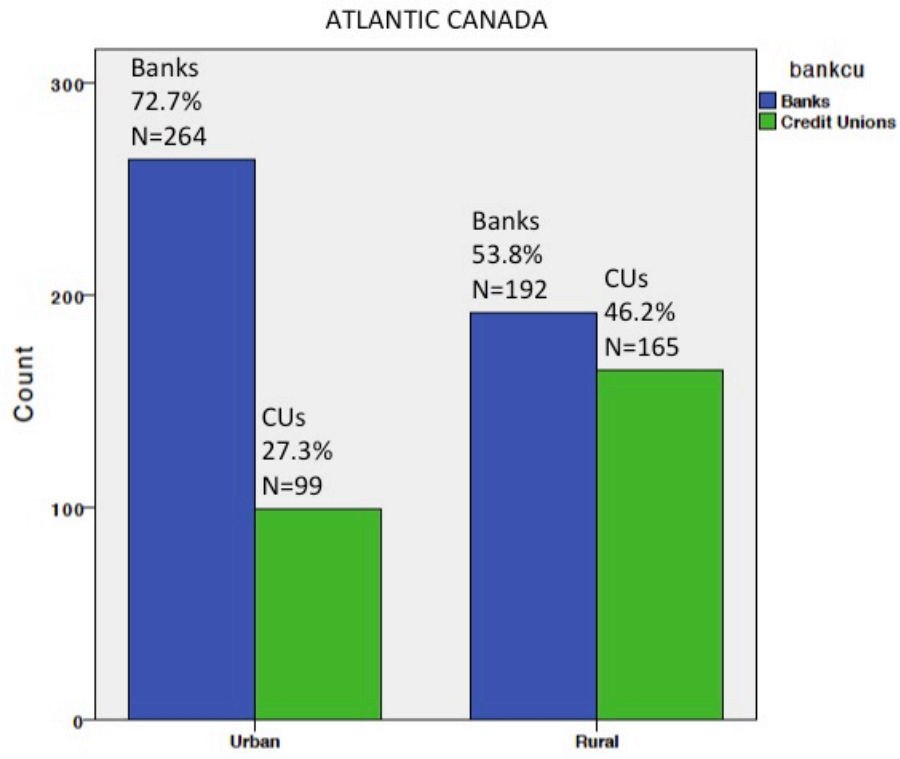

Note: Missing: 0 Chi-square $=27.820$, d.f. $=1, p<.000$ Cramer's V $=.197$

For Québec the more extreme spread is in the rural and small towns (populations 8,000 or less). In Québec caisses populaires constitute $81 \%$ of the total, while banks make up 19\%. In urban areas in Québec, caisses populaires make up $41 \%$ of the total, while banks are $59 \%$.

\section{Qualitative study}

To interpret the pattern of the data, we sought out key informants who were knowledgeable about the field. With the assistance of contacts in the credit union sector, we were able to recruit and interview seven leaders from credit unions and caisses populaires across Canada:

- Vivian Campbell, Senior Consultant, Credit Union Services, Atlantic Central

- Art Chamberlain, Media Relations Manager, Central 1 Credit Union, representing British Columbia and Ontario

- Bill Langthorne, CEO, Credit Union Deposit Guarantee Corporation (CUDGC), Alberta, and Superintendent of Credit Unions

- lan MacPherson, Emeritus Professor of History, University of Victoria, specializing in the study of cooperatives and credit unions, and board member of British Columbia Credit Union Central

- Alvina O'Brien, CEO, Eagle River Credit Union, Newfoundland and Labrador

- Daniel Roussel, Advisory Manager, Cooperative Development and Democratic Governance Support, Mouvement Desjardins, Québec

- Dale Smith, Executive Manager, Business Strategy \& Innovation, TCU Financial Group, Saskatoon

The interviewees were asked to give their overall impressions of our quantitative findings and say how they might explain them. We also asked whether they believed the geographic distribution of credit unions was strategic (i.e., to avoid 
competition with urban banks) and whether they believed that credit unions were filling a niche in rural and small communities (where there are fewer banks). Some of our interviewees were able to offer a broad or historical perspective on Canada's credit union sector, while others provided insight into specific regional concerns.

\section{Interview data findings}

In general, interview responses could be collapsed into two broad themes: 1) explanations as to why credit unions are a better match for rural and small communities, or put differently, the difference between credit unions/caisses populaires and banks; 2) the reasons why credit unions and caisses populaires are underrepresented in large urban centres. Here we address these themes in turn.

\section{The credit union/caisse populaire cifference}

Credit unions and caisses populaires offer many services that are similar to banks, but the interviewees emphasized the differences-both historical and philosophical. All of the interviewees alluded to one fundamental distinction: the primary orientation of banks is to meet the needs of their shareholders to make money, while the primary orientation of credit unions and caisses populaires is to provide a service to their members, and not to maximize profit. This should be viewed as a difference in degree, not a categorical difference, as service is also a priority for banks, and having a positive net income is of importance to credit unions and caisses populaires. Nevertheless, as one of the interviewees told us, "Credit unions are not as profitdriven as banks." Other interviewees made the same point in reference to the role that credit unions play in sustaining rural and small communities. When banks close branches in rural communities and small towns as a cost-cutting measure, credit unions and caisses populaires often become the only local financial institutions and provide services that the people in these communities would not be able to access otherwise. In the words of another interviewee, "Banks just don't want to be bothered [with rural and small communities]."

The interviewees also highlighted the differing historical roots of credit unions/caisses populaires and banks. One interviewee noted that Saskatchewan's economy revolved around agriculture for much of the twentieth century, though recently mining of potash and oil and gas exploration have assumed greater importance. During the Great Depression, when banks would not finance farmers, credit unions were established in many of Saskatchewan's communities. Looking at more contemporary times, the tendency for a credit union to maintain its presence in rural communities and small towns was noted. One interviewee described how credit unions took over bank locations when one of the major banks embarked on a branch reduction strategy in Western Canada ten years ago, saying: "It was a good business decision for the banks and for the credit unions."

Similarly, in the Atlantic, one of our interviewees noted the historical connection to the Antigonish Movement of the 1930s, when Catholic parishes led the organizing of credit unions. The interviewee emphasized that the over-representation of credit unions in rural and small communities "isn't part of a strategy to go to these areas." Instead, "Credit unions have made a concerted effort to stay in rural and small communities."

Another interviewee highlighted the historical uniqueness of Canadian credit unions, many of which emerged out of communities, churches, unions, and employee groups. This model, it was noted, was largely retained until the 1970s. However, there are significant regional differences in the historical development of credit unions. One interviewee noted that credit union growth in Newfoundland was, for the most part, driven by government-funded rural development organizations in communities needing a lower-cost service or a financial institution.

The interviews suggest that there is a difference in philosophy among credit unions that distinguishes them from banks and a difference in tradition because credit unions have historical ties to rural and small communities that 
have persevered in spite of modernizing trends. As one interviewee told us, "There has always been a tendency to be closely identified with constituencies, and this impeded growth in some ways." The constituencies could also be referred to as communities, either geographic or of mutual interest.

\section{Under-representation in large urban centres}

The data indicate that not only are credit unions and caisses populaires more prevalent in rural and small communities, but that they are also under-represented in large urban centres. To some extent, the relationship is reciprocal, but the interviewees discussed both and provided different explanations for the underrepresentation. Desjardins, arguably, is the strongest system of financial cooperatives in Canada, but as noted, the rural tilt is striking. One interviewee emphasized this point, stating that in rural and small communities about $80 \%$ of residents belong to the local caisse populaire, whereas in Montreal it is only $30 \%$. It was explained that "Montreal is more Anglophone and more multicultural, whereas caisses have traditionally been more francophone and more Roman Catholic"-in other words, there isn't as good of a cultural fit. Catholic parishes in Québec were leaders in organizing caisses populaires early in the twentieth century, and to a degree this connection has been maintained. In Montréal, however, the population is more cosmopolitan, more diverse, and more secular. Desjardins competes with the large banks in Montréal, where it lacks the dominance it has in small communities. Our Desjardins interviewee acknowledged this point: "It is difficult for caisses populaires to compete with banks." Another interviewee noted that the prohibitive cost of advertising makes it difficult for credit unions to develop visibility and brand recognition in large urban markets like Toronto.

One interviewee viewed the growing centralization of services by credit unions and caisses populaires as an attempt to compete more effectively with the banks. He argued that historically credit unions have engaged in "conservative entrepreneurship." Credit union board members, the interviewee stated "are not flamboyant risktakers. They are aware that they are looking after their own funds, as well as those of their parents and neighbours, and will not go too far out on a limb." It was noted that credit union mergers inevitably lead to centralization, and "greater centralization on the business side" can enable a credit union to offer a wider range of services and products (and compete more effectively with the banks). Another interviewee, however, raised some doubts about this strategy: "Mergers and amalgamations can help credit unions to create a stronger image. But it is not just about image. Credit unions need to offer a distinguishable service to members, like Mountain Equipment Co-operative does."

To some extent technological changes such as electronic banking have overridden geographic locations. This cuts two ways: one interviewee argued that "the bricks and mortar presence of credit unions is misleading because with the rise of electronic services, all areas can be served," meaning that credit unions can serve a clientele in large urban centres even though they lack a strong physical presence there. However, another interviewee raised concerns about the opposite impact of electronic banking, that banks are able to serve a clientele in rural and small communities even though they have closed their branches there: "People's savings are going into ING, PC, Manulife, but the people still want the [Desjardins] outlets. ... If you want the caisse to be a part of the community, the community should be part of the caisse."

\section{DISCUSSION}

Our findings indicate that credit unions and caisses populaires are found disproportionately in rural and smalltown Canada, much like other cooperative enterprises that function independently of government programs (Quarter et al., 2012). The explanations of the data from the interviews suggest that a number of factors come into play: the credit union/caisse populaire tradition of being founded in rural and small-town Canada, the 


\section{Mook, Hann, and Quarter (2012)}

abandonment of small communities by the large banks, and the challenges for credit unions and caisses populaires to compete with the banks in large urban centres.

Market-failure theory has been applied to explain why organizations in the social economy or third sector are not more central to the economy, and the theory generally argues that such organizations emerge where the private sector loses interest because of insufficient profits (Ben-Ner, 1986; Hansmann, 1980; Weisbrod, 1974, 1977). The evidence that banks are abandoning rural and small communities and credit unions and caisses populaires are filling the void would be consistent with market-failure theory. For example, in the early 2000s, credit unions in British Columbia, Alberta, Saskatchewan, Manitoba, New Brunswick, and Nova Scotia purchased more than 70 bank branches in communities where the six major banks ${ }^{4}$ had decided they would no longer operate (Canada, Department of Finance, 2003). However, market failure appears to be an overly simplistic explanation for this phenomenon. As noted, credit unions and caisses populaires have a lengthy history in some RST communities and have decided to stay there even though the net income might be greater in a more densely populated area. Provinces such as Saskatchewan and Québec, with a highly disproportionate number of credit unions in rural and small-town areas, are also those in which credit unions have had lengthy histories.

A likely reason that credit unions remain in rural and small-town Canada concerns their member-based governance, a point that was raised in the introduction to this paper. As one interviewee commented, it is very difficult to close a credit union once it is established within a community (see also Sriram [2000] on this same point, with respect to Desjardins). The difficulty in closing credit union branches can be viewed as a function of a democratically elected board representing the members of a community with an interest in preserving the credit union. Bank executives do not face similar challenges in closing their branches.

The willingness of credit unions to stay put might be viewed as part of the so-called cooperative difference; they are there to provide a service to members, not to maximize the returns to investors who may have no connection to small and rural communities. In the words of one interviewee: "When a credit union wants to close a branch, all hell will break loose-boards are reluctant to do this. When amalgamations happen, no staff will be lost, and no branches will be closed." Mergers can lead to criticism from management as well as members, for example, Claude Béland, past president of Mouvement Desjardins, recently stated on CBC-Radio Canada that Desjardins' cooperative philosophy has been weakened by mergers (CBC-Radio Canada, 2011). Banks are also scrutinized by the public, but not over issues such as democratic practices, but rather whether their profits are meeting expectations (a concern of investors) and whether their charges are excessive (a concern of consumers and public officials).

Put differently, it could be argued that financial cooperatives face greater social expectations than banks. When cooperatives merge to compete more effectively with banks, they are held to a standard by their members. Banks have to be wary of consumer concerns, but unlike credit unions, their consumers are not active participants in decisions about mergers and location changes, but rather a passive voice taken into consideration by management. For credit unions, the consumers are members who are entitled to demand more, as a fundamental part of the cooperative difference. Moreover, as noted in Ketilson and Brown (2011), credit unions value member participation and are trying to find ways to keep their members engaged in decision-making with larger merged structures.

When credit unions and caisses populaires are viewed in relation to the overall market, they may be seen as a niche player specializing in consumer loans to members and to small businesses owned by their members. They are able to thrive in smaller communities because, in the words of one interviewee, "Rural areas are more co-op minded." Often credit unions are set up with the support of a sponsoring organization: a religious 
congregation, ethnocultural association, workplace, or union. In some small communities, credit unions operate within a cluster of cooperatives-a store serving consumers, gas bar, et cetera. The Evangeline Credit Union in the Acadian region of Prince Edward Island is a classic example of this arrangement (Wilkinson \& Quarter, 1996).

Therefore, even though elements of the data suggest that credit unions have agreed to operate within a space where the private sector is failing to deliver services, in the main the data suggest that credit unions serve a niche much like businesses in general. It is risky to compete against the large banks in major urban centres that are already saturated with financial institutions. It appears, as noted, that credit unions and caisses populaires are gearing up to do this by engaging in mergers that have sharply reduced the number of independent organizations. It remains to be seen whether this strategy will either lead to a stronger presence in urban centres or reduce the disproportionate credit union presence in rural and small-town Canada.

Another issue raised in the interviews that bears scrutiny is electronic banking. It was raised primarily in the context of Desjardins but could be described as the proverbial elephant in the room. One component of the socalled co-op advantage is that the consumers of the service are also members with presumably a greater commitment to the firm than the consumers of a bank. Applying the theory of Hirschman (1970), one might expect that members of a credit union would be less likely to exit than the clients of a bank, since membership implies a greater level of commitment than the consumption of services. This is a hypothetical point that has been made previously in the context of cooperatives (e.g., Jordan, 1989). However, this point requires empirical proof. The advent of electronic banking may create the context for such a test.

As noted above, electronic banking, like electronic communication in general, extends the geographic reach of service users. Part of the cooperative advantage in rural and small-town Canada is its physical location within the community. This may be viewed as a competitive advantage that gives credit unions an edge in the market, as derived from market-advantage theory (Barney, 1991). It is less likely that residents of a small town will drive to a bank at some distance when a credit union is within walking distance. With electronic banking, will that continue to matter? Will that competitive advantage in small towns be lost with increased use of electronic services? At present, one advantage that banks have in urban markets is the convenience of branches in close proximity to clients; will credit unions be better able to penetrate urban markets because of electronic banking? One example of a cooperative that has been successful in engaging its members through the Internet is Mountain Equipment Co-op (MEC). The Internet allows MEC to sell to an international market and to engage thousands of participants in its annual general meeting (Quarter, Mook, \& Armstrong, 2009). Credit unions may be able to follow the MEC example in the use of the Internet. This is something that should be observed carefully.

\section{DIRECTIONS FOR FURTHER RESEARCH}

Although this study proceed inductively, it speculates about possible explanations for the data, one being that the democratic structure of credit unions and caisses populaires makes it more challenging to move from a community once it is situated there. This hypothesis is something we intend to test as we extend the research to other jurisdictions, for example, parts of the United States, where data are currently being collected. If the democratic structure of cooperatives inhibits closing locations, one might expect that new credit unions would more likely be urban than older credit unions. Given the different contexts and legal environments, a comparative analysis with a rural/urban lens would bring additional insights to understanding why cooperative organizations are situated where they are. 
Also, with electronic banking becoming the norm rather than exceptional, it will be interesting to observe the impact upon credit unions: both their competitive advantage in small-town Canada and their ability to penetrate urban markets. It would be useful to know whether membership in a credit union increases customer loyalty beyond what it would be for a bank.

It will also be interesting to follow the trend among credit unions and caisses populaires and see whether amalgamations reduce the proportion of credit unions that are located in rural and small-town Canada. Mergers, of course, decrease the number of distinct credit unions, and this would pertain to urban centres also. However, mergers may lead to increased memberships and larger assets. It is too early to determine whether this goal will succeed; at present, the primary niche for financial cooperatives appears to be rural communities and smalltowns across Canada.

\section{CONCLUSION}

This study explores whether there is a rural tilt among credit unions and caisses populaires in Canada, using location of outlets as a measure. The data clearly show a pattern of over-representation of credit unions and caisses populaires in rural communities. The pattern is uneven across the country but there is overrepresentation in all parts, especially in Québec and Saskatchewan. Bank locations in Québec and Atlantic Canada, by comparison, more closely reflected the population distribution.

The strength of this study is the empirical pattern it presents. The weaknesses are whether location is the best measure to use, given the advent of electronic banking. For example, it is possible that residents in a location are using electronic means to access a financial institution located elsewhere. A second weakness of the study is that it does not test a theory; rather, because it proceeds inductively, it speculates about possible explanations for the data. A formal test of the phenomena discerned in this study is needed. For example, given the speculative argument that the democratic structure of credit unions may make moving from a community more difficult, one might expect that newer credit unions are more likely to be urban. This hypothesis could be tested empirically.

This study may create a better understanding as to why credit unions and perhaps cooperatives more generally are more tilted to rural areas, given the current population distribution. Whether this understanding is of practical use depends upon whether members want to change that pattern. The unique feature of credit unions and cooperatives is that the members have a choice, should they decide to exercise it.

\section{ACKNOWLEDGEMENTS}

We would like to thank the following individuals for their cooperation in this study: Vivian Campbell-Senior Consultant, Credit Union Services, Atlantic Central; Art Chamberlain-Media Relations Manager, Central 1 Credit Union; Bill Langthorne-CEO, CUDGC, and Superintendent of Credit Unions; Alvina O'Brien-CEO, Eagle River Credit Union; lan MacPherson, Emeritus Professor of History, University of Victoria, and long-time board member of the British Columbia Credit Union Central; Daniel Roussel-Advisory Manager, Cooperative Development and Democratic Governance Support, Mouvement Desjardins; Dale Smith-Executive Manager, Business Strategy and Innovation, TCU Financial Group. 


\section{Mook, Hann, and Quarter (2012)}

\section{NOTES}

1. Appendix A shows the credit union and caisse location Websites accessed for this study.

2. Service outlets are typically smaller than branches, with fewer staff and facilities.

3. Appendix $B$ shows the percentage of credit unions and banks of the total of both by province and population distribution.

4. The six major banks are RBC, TD Canada Trust, Scotiabank, BMO, CIBC, and National Bank.

\section{REFERENCES}

Barney, J. (1991). Firm resources and sustained competitive advantage. Journal of Management, 17, 99-120. Ben-Ner, A. (1986). Non-profit organizations: Why do they exist in market economies? In S. Rose-Ackerman (Ed.), The economics of nonprofit institutions: Studies in structure and policy (pp. 94- 113). Oxford: Oxford University Press.

Benson, M. (2002). Conflict, co-operation, and culture: A study in multiparty negotiations. Saskatoon, SK: Centre for the Study of Co-operatives, University of Saskatchewan.

Canada. Department of Finance. (2003). Canada's credit unions and caisses populaires. URL: http://www.fin.gc.ca/activty/factsheets/ccu_e.pdf [January 5, 2012].

CBC-Radio Canada. (2011). The cooperative spirit of Mouvement Desjardins is in question [Translated from French]. URL: http://www.radio-canada.ca/nouvelles/Economie/2011/04/06/015-desjardins-caissesproximite.shtml [August 26, 2011].

Co-operatives Secretariat. (2011). Co-operatives in Canada, 2007. URL: http://www.coop.gc.ca/COOP/displayafficher.do?id=1233009297681\&lang=eng\#ann [January 15, 2012].

Cornforth, C. (2002). Making sense of co-operative governance: Competing models and tensions. Review of International Co-operation, 95(1), 51-57.

Cornforth, C. (2004). The governance of co-operatives and mutual associations: A paradox perspective. Annals of Public and Co-operative Economics, 75(1), 11-32.

Credit Union Central of Canada. (2011). System results. URL: http://www.cucentral.com/SystemResults4Q10 [August 26, 2011].

Creswell, J. W. (1998). Qualitative inquiry and research design: Choosing among five traditions. Thousand Oaks, CA: Sage Publications.

Creswell, J. W. (2003). Research design: Qualitative, quantitative, and mixed approaches. Thousand Oaks, CA: Sage Publications.

Creswell, J. W., \& Plano Clark, V. L. (2007). Designing and conducting mixed methods research. Thousand Oaks, CA: Sage Publications.

Desjardins. (2011). Desjardins figures, December 31, 2010. URL: http://www.desjardins.com/en/a_propos/quinous-sommes/chiffres.jsp [August 26, 2011]

Du Plessis, V., Beshiri, R., Bollman, R. D., \& Clemenson, H. (2001). Definitions of rural. Rural and Small Town Canada Analysis Bulletin, 3(3). URL: http://www.statcan.gc.ca/pub/21-006-x/21-006-x2001003-eng.pdf [August 26, 2011].

Hansmann, H. (1980). The role of nonprofit enterprise. Yale Law Journal, 89, 835-901.

Hirschman, Albert O. (1970). Exit, voice, and loyalty. Cambridge, MA: Harvard University Press.

Jordan, J. (1989). The multi-stakeholder concept of organization. In J. Quarter \& G. Melnyk (Eds.)., Partners in enterprise: Worker-ownership in Canada (pp. 113-131). Montréal, QC: Black Rose Books.

Ketilson, L. H., \& Brown, K. (2011). Models for effective credit union governance: Maintaining community connections following a merger. Saskatoon, SK: Centre for the Study of Co-operatives, University of Saskatchewan. 


\section{Mook, Hann, and Quarter (2012)}

MacPherson, I. (1979). Each for all: A history of the co-operative movement in English Canada: 1900-1945. Toronto, ON: Macmillan.

MacPherson, I. (1995). Co-operation, conflict and consensus: BC Central and Credit Union Movement to 1994. Vancouver, BC: Credit Union Central of BC.

MacPherson, I. (1999). Hands around the globe: A history of the international credit union movement and the role and development of the World Council of Credit Unions, Inc. Victoria, BC: Horsdal \& Schubart.

MacPherson, I. (2012). Historic changes in the Canadian credit union movement. In L. Mook, J. Quarter, \& S. Ryan (Eds.), Businesses with a difference: Balancing the social and economic (pp. 19-39). Toronto, ON: University of Toronto Press.

Mavenga, Fortunate. (2011). Economic impact of credit unions on rural communities. Unpublished master's thesis, University of Saskatchewan, Saskatoon, SK.

Quarter, J., Mook, L., \& Armstrong, A. (2009). Understanding the social economy: A Canadian perspective. Toronto, ON: University of Toronto Press.

Quarter, J., Mook, L., \& Hann, J. (2012). Non-financial co-operatives in Canada: 1955 to 2005. In L. Mook, J. Quarter, \& S. Ryan (Eds.), Businesses with a difference: Balancing the social and economic (pp. 4263). Toronto, ON: University of Toronto Press.

Spear, R. (2004). Governance in democratic member-based organisations. Annals of Public and Cooperative Economics, 75(1), 33-60.

Sriram, S. N. (2000). Financial co-operatives in Québec, Canada: A study of the Desjardins movement. Journal of Rural Development, 19(2), 161-183.

Statistics Canada. (2008). Population and dwelling counts, for Canada, provinces and territories. URL: http://www12.statcan.ca/english/census06/data/popdwell/Filter.cfm?T=202\&GK=1\&RPP=50 [January 18, 2012].

Tashakkori, A., \& Teddlie, C. (Eds.). (2003). Handbook of mixed methods in social and behavioural research. Thousand Oaks, CA: Sage Publications.

Theriault, L., Skibbens, R., \& Brown, L. (2008). A portrait of co-operatives and credit unions in Atlantic Canada: Preliminary analysis. Working Paper 2008-01. Halifax, NS: Social Economy and Sustainability Research Network.

Weisbrod, B. (1974). Toward a theory of the voluntary non-profit sector in a three-sector economy. In E. Phelps (Ed.), Altruism, morality and economic theory (pp. 171-195). New York, NY: Russell Sage.

Weisbrod, B. (1977). The voluntary non-profit sector. Lexington, MA: D. C. Heath \& Co.

Wilkinson, P., \& Quarter, J. (1996). Building a community-controlled economy: The Evangeline co-operative experience. Toronto, ON: University of Toronto Press.

\section{ABOUT THE AUTHORS / LES AUTEURS}

Laurie Mook is an Assistant Professor in the School of Community Resources and Development at Arizona State University. Email: Imook@asu.edu

Jennifer Hann is a Master's student at the Ontario Institute for Studies in Education, University of Toronto. Email: jennifer.hann@utoronto.ca

Jack Quarter is a Professor and Co-director of the Social Economy Centre at the Ontario Institute for Studies in Education, University of Toronto. Email: jack.quarter@utoronto.ca 